\title{
The Inextricable Path from a Deathbed to the Fight Against Impunity: The Cases of Franco and Pinochet
}

Rosa Ana Alija Fernández

\section{Address}

Departament de Dret Penal i Criminologia, i Dret Internacional Públic i Relacions Internacionals Universitat de Barcelona

Avda. Diagonal, 684

08034 Barcelona

Spain

Email: ralija@ub.edu

Tel. : +34 934020879

\section{Biographical Notes}

Rosa Ana Alija Fernández, Dr. eur., is a Reader at the Department of Criminal Law and Criminal Sciences, and Public International Law and International Relations at the University of Barcelona. Her main teaching and research areas are international law, international human rights law, international criminal law, and transitional justice. She has been a visiting professor at the University of Puerto Rico and a visiting researcher at the University of Uppsala, and at the Research Centre in Latin-American Criminal and Procedural Law (Forschungsstelle für lateinamerikanisches Straf- und Strafprozessrecht) at the University of Göttingen. She has collaborated with the International Criminal Tribunal for Rwanda in training Rwandan lawyers on universal jurisdiction, and with international research teams and networks in the field of transitional justice. Among her publications are La persecución como crimen contra la humanidad (Barcelona: Universidad de 
Barcelona, 2011) and, with Jordi Bonet Pérez, Impunidad, derechos humanos y justicia transicional (Bilbao: Universidad de Deusto, 2009).

\begin{abstract}
Although Francisco Franco and Augusto Pinochet both died of natural causes, and neither of them were put on trial for the crimes committed under their regimes, their bodies did not share the same fate. A comparison of these two cases reveals how the treatment of a perpetrator's corpse can, from the point of view of the international protection of human rights, constitute an obstacle to ending the impunity enjoyed by those responsible for the abuses. Conversely, the fight against that impunity can have a decisive bearing on the treatment applied to the remains of the deceased perpetrator. A close link may in fact be discerned between the fate of the corpses of mass criminals and the fight against impunity, along with the policy of commemoration, which is pursued - or not - by the state.
\end{abstract}

Keywords: Franco; Pinochet; impunity; memorials; natural death; mass crimes; dictatorship; human rights.

Word Count: 8329 (footnotes included) 


\section{Introduction}

The year 1975 saw Augusto Pinochet's sole official visit to Spain. The reason was to attend Francisco Franco's funeral. ${ }^{1}$ Pinochet had come to power only two years earlier, when he led the coup d'état that killed Salvador Allende and imposed a dictatorship that would not end until 1990. However, Pinochet remained a strong presence on the Chilean public scene until he died of a heart attack in 2006. Pinochet travelled to Madrid to pay a posthumous tribute to Franco that he most likely thought was well-deserved for having led his country with an iron fist for almost forty years. It was a bombastic tribute, in line with the one he surely yearned for himself, but which never happened, as major changes came about in Chile before his death.

The "death connection" between Pinochet and Franco illustrates the strong affinity between the two dictators, who had a lot in common. For example, both died of natural causes without a criminal conviction for the serious human rights violations committed during their regimes. However, one of the most notable differences between them may be observed precisely in the way their dead bodies were dealt with. In fact, the treatment they were given reflects, and is the culmination of, their divergent stories in at least two aspects. One is the period of time they were in power (almost four decades in the case of Franco, who died in power, versus less than two decades in the case of Pinochet, who was forced from power sixteen years before his death). The other aspect is the opening of criminal investigations into human right violations, which was unthinkable and impossible in Franco's Spain, but was viable in post-Pinochet Chile, more exposed to international human rights law, which had witnessed significant advances since the death of the Spanish dictator. ${ }^{2}$

\footnotetext{
${ }^{1}$ The Chilean dictator, Rainier III, Prince of Monaco and King Hussein of Jordan were the only heads of state who attended the funeral.
}

${ }^{2}$ At the time of Franco's death not even the International Covenant on Civil and Political Rights (ICCPR) or the International Covenant on Economic, Social and Cultural Rights (ICESCR) were in 
On this basis, this article will focus on analysing, from a human rights perspective, how the treatment of the corpse of an executioner who died of natural causes can interact with the fight against impunity. More specifically, it will deal with two of the central principles in this discussion: the obligation of the state to preserve memory and the victims' right to justice. ${ }^{3}$ In this particular case, we will compare how the treatment that Franco's body received has influenced the fight against impunity in Spain - in terms of the duty to remember - and how the fight against impunity in Chile - in terms of the right to justice - has influenced the treatment given to Pinochet's body.

To elaborate on these issues, we first will analyse the treatment given to Franco's body and its effects, which continue to this day, on the duty of the Spanish state to preserve memory. Next, we will look at how the attempts to take Pinochet to court in his final years of life might have conditioned the treatment his body received. To conclude, we will present a series of final remarks regarding interactions between natural death and the fight against impunity.

\section{Franco, the Valle de los Caídos and the Historical Memory Law: The (De)Monumentalization of the Dictator's Dead Body}

force (both of 1966, they came into effect in 1976), and the United Nations Commission on Human Rights (UNCHR) only recently had created extra-conventional mechanisms to protect human rights. Thus, in 1967 the use of special procedures was authorized by the ECOSOC Resolution 1235 (XLII), which led to the creation of an ad hoc working group on Southern Africa, followed in 1975 by an ad hoc working group on the situation of human rights in Chile; in 1970 ECOSOC Resolution 1503 (XLVIII) established a confidential complaint procedure.

${ }^{3}$ Updated Set of Principles for the Protection and Promotion of Human Rights Through Action to Combat Impunity - Report of Diane Orentlicher, independent expert to update the Set of Principles to Combat Impunity, Addendum, UN Doc. E/CN.4/2005/102/Add.1, 8 February 2005, II (principle 3) and III, respectively. 
Francisco Franco's natural death left his regime without its founding figure and opened the way to a period of political change, potentially capable of putting an end to the model imposed by the dictator, the repression, and the serious violations of human rights. However, the treatment his dead body received largely reflects the efforts made to perpetuate Francoism, whose effects still can be seen today, despite the fact that the Spanish transition tends to be presented as a completed and successful project to consolidate peace and democracy. However, the transition is far from being a model process when the benchmark is human rights and the fight against impunity. Throughout the twenty-first century, the demands of the victims and their descendants finally have moved beyond the private sphere into the public scene, which shows that the pact to move forward and forget - the cornerstone of the Spanish transition - has not satisfied those who suffered the atrocities and excesses of the dictatorship. In this context, the way to deal with the symbolism around the figure of the dictator is still a matter of debate that affects the construction of collective memory and perpetuates a sensation of impunity in Spanish society.

We now will proceed to analyse the treatment given to Franco's dead body. Next, we will deal with the problems arising from the perspective of the protection of human rights in the context of the fight against impunity (particularly in terms of the state's duty to preserve memory), highlighted by the adoption of the 2007 Historical Memory Law (henceforth HML) and the debate it opened in terms of what to do with the dictator's tomb.

\section{The Symbolic Value of Franco's Mortal Remains}

General Francisco Franco died at the Hospital de la Paz in Madrid on 20 November 1975, two weeks before turning eighty-three years old. He had held power for almost forty years $\left(1936^{4}\right.$ -

${ }^{4}$ Francisco Franco was appointed as head of the government of Spain by Decree no. 138 of the Junta de Defensa Nacional, of 29 September 1936, published in Boletín Oficial de la Junta de Defensa de España, no. 32, 20 April 1936, 125-6. He was in power de facto until he declared 
1975), first as the leader of the military coup that started the Spanish Civil War (1936-1939), and then as a self-proclaimed Caudillo, the strong man of a state under a personalist dictatorial regime. His person was the foundation of Francoism, the ideology and social model forged and consolidated throughout his dictatorship. The dictator's persona became so essential in the state model he created that, even after his death, he continued to a large extent to steer the destiny of Spain in the short-, medium-, and long-term. In fact, even when his death was inevitable, his doctors did everything they could to keep him artificially alive, ${ }^{5}$ an effort that allegedly had political motivations. ${ }^{6}$ Franco's body thus became a metaphor for the need to keep a dying regime alive at all costs. Furthermore, once he passed away, his date of death was charged with symbolism as it was scheduled to coincide with that of José Antonio Primo de Rivera, ${ }^{7}$ founder of the Spanish Falange.

himself head of state in article 2 of the Ley de Sucesión en la Jefatura del Estado [Political Succession Law], published in Boletín Oficial del Estado, no. 208, 27 July 1947, 4238.

${ }^{5}$ Vicente Pozuelo Escudero, Los Últimos 476 días de Franco (Barcelona: Planeta, 1980), 241. Ricardo de la Cierva noted that on 19 November, Franco's life practically was artificial. Ricardo de la Cierva, Franco (Barcelona: Planeta, 1986), 502.

${ }^{6}$ Despite the fact the family wanted to let him die so he would stop suffering. De la Cierva, Franco, 502. There was an interest in extending his life so he would be able to renew the position of the president of the National Congress and of the Kingdom of Spain Council - whose term ended on November 26 - to ensure the Council (and, consequently, the appointment of the future heads of government) would stay under the control of a person of trust. Stanley G. Payne, Franco: El perfil de la historia (Madrid: Espasa Calpe, 1992), 252-3; Paul Preston, Franco: "Caudillo de España" (Barcelona: DeBolsillo, 2004), 839.

${ }^{7}$ Franco was clinically dead late in the afternoon of 19 November 1975. De la Cierva, Franco, 503. Soon after that, his family decided to disconnect him from the life support systems. Preston, 
Renamed "Falange Española Tradicionalista y de las Juntas de Ofensiva Nacional Sindicalista"

(Falange Española de las JONS), and led by Franco, it was to become the sole political party permitted by the dictatorship. ${ }^{8}$

Further to that, in his capacity as head of state until the day of his death, he had long before dying decided both Spain's destiny and his own. Thus, he secured institutional continuity (starting with his successor as head of state ${ }^{9}$ ) legally constructed during his rule, one which would, in fact, be used to transform his authoritarian system into a democratic regime. ${ }^{10} \mathrm{He}$ had also made a decision regarding where his remains would be interred. The chosen place was the Valle de los Caídos [Valley of the Fallen], a massive architectural ensemble ${ }^{11}$ that included a monastery, a basilica and a monumental cross in the province of Madrid. ${ }^{12}$ Its

Franco, 839. However, the official time of death was set in the early hours of 20 November, the date when José Antonio Primo de Rivera was executed in 1936.

${ }^{8}$ Decree no. 255, of April 19, 1937, published in Boletín Oficial del Estado, no. 182, 20 April 1937, 1033-4. This decree stated that the Spanish Falange and Requetés were to merge - under the command of the head of state - into a single national political entity named Falange Española Tradicionalista de las JONS, and that all other political organizations and parties had to be dissolved.

${ }^{9}$ In accordance with the provisions of the Ley de Sucesión en la Jefatura del Estado, Franco appointed Juan Carlos de Borbón as his successor; this was confirmed by the National Congress on 22 July 1969.

${ }^{10}$ See Payne, Franco, 268-71.

${ }^{11}$ Calleja sees this as "Franco's megalomaniac obsession with being immortalized and defying time.” José M. Calleja, El Valle de los Caídos (Madrid: Espasa, 2009), 20.

${ }^{12}$ Given that during the Francoist dictatorship Spain was formally a kingdom (article 1 of the Ley de Sucesión en la Jefatura del Estado), it is significant that the Valle de los Caídos is located only 
construction was ordered in 1940 to perpetuate the memory of the fallen in the "Glorious Crusade," 13 that is, the soldiers commanded by Franco - the Nationalist faction - who died in the Spanish Civil War. ${ }^{14}$ There was an attempt to tone down the exclusionary nature of this monument, which ostracized the fallen Republican soldiers, through the decree-law issued in 1957 that created the Fundación de la Santa Cruz del Valle de los Caídos [Saint Cross of the Valley of the Fallen Foundation], whose preamble stated,

... the long years of peace that have followed the Victory have seen the development of a policy guided by the highest sense of unity and brotherhood among the people of Spain. This has to be, therefore, the Monument to all the dead, over whose sacrifice the pacific arms of the Cross will rise triumphant. ${ }^{15}$

However, the way this alleged attempt at reconciliation was carried out was hardly respectful of the dead soldiers of the republic: their bodies were exhumed, without informing their families or

ten kilometres away from the Monastery of San Lorenzo of El Escorial, where the House of Austria and the Bourbon monarchs traditionally have been buried. See Fernando Olmedo, El Valle de los Caídos. Una memoria de España (Barcelona: Península, 2009), 337-8.

${ }^{13}$ Decree of 1 April 1940, stating that a Basilica, Monastery and Cuartel de Juventudes [Youth Quarters] should be built in the estate located at the slopes of the Sierra del Guadarrama (El Escorial), known as Cuelgamuros, "to preserve the memory of the fallen in our Glorious Crusade," published in Boletín Oficial del Estado, no. 93, 2 April 1949, 2240.

${ }^{14}$ According to the preamble of the Decree of 1 April 1940, it was intended to be "the glorious temple dedicated to our dead and where those who fall in the service of God and the Fatherland will be prayed for. It will be a perpetual place of pilgrimage, the magnificent natural setting of which will provide a dignified setting for the resting place of those who gave their lives in the Crusade." ${ }^{15}$ Published in Boletín Oficial del Estado, no. 226, 5 September 1957, 834. 
asking their authorization, and were moved from all over Spain to the Valle de los Caídos. ${ }^{16}$ Approximately twenty thousand bodies remain unidentified to this day. ${ }^{17}$ If we add to that the number of political prisoners who participated in the construction of the complex in exchange for sentence reductions, ${ }^{18}$ the monument becomes a symbol of the humiliation of the losing side, rather than the hymn to unity it proclaimed itself to be. ${ }^{19}$ The Valle de los Caídos was inaugurated in 1959, and to this day it remains officially recognized as part of Spain's national heritage.

The decision to place Franco's remains in the basilica of the Valle de los Caídos seems to have been made before its inauguration. Those in charge of designing it planned a pit at the rear of the crypt $^{20}$ and Franco confirmed his desire to be buried there on the day of its inauguration. ${ }^{21}$

${ }^{16}$ Calleja, El Valle de los Caídos, 112-20.

${ }^{17}$ Ibid., 113. The official data estimates that 12,410 unknown persons were buried in the Basilica. Comisión de Expertos sobre el Futuro del Valle de los Caídos (CEFVC), Informe, Madrid, 2011, para. 1.

18 Daniel Sueiro, El Valle de los Caídos. Los secretos de la cripta franquista [1976] (Barcelona: Argos Vergara, 1983), 24-96; Calleja, El Valle de los Caídos, 97-108. Architect Diego Méndez noted that only forty-six people worked at the Valle de los Caídos to shorten their sentences, though in fact this number was higher. Torres speaks of twenty thousand Republican prisoners, but Lafuente adjusts these numbers and estimates that between six and seven thousand prisoners worked on the construction of the complex. Diego Méndez, El Valle de los Caídos. Idea, proyecto y construcción (Madrid: Fundación Nacional Francisco Franco (FNFF), 1982), 273; Rafael Torres Mulas, Los Esclavos de Franco (Madrid: Oberon, 2001), 157; Isaías Lafuente, Esclavos por la patria. La explotación de los presos bajo el franquismo (Madrid: Temas de Hoy, 2002), 119. ${ }^{19}$ For Calleja, it is a "certificate of defeat for the others, for the non-Spaniards of 'anti-Spain."” Calleja, El Valle de los Caídos, 27. See also CEFVC, Informe, para. 5.

${ }^{20}$ Méndez, El Valle de los Caídos, 291; Sueiro, El Valle de los Caídos, 208. 
However, this decision was not known until the moment of his death and was a complete surprise to many who thought Franco would be buried at the Palace of El Pardo, his official residence. ${ }^{22}$ In fact, testimonies of the period note that when Franco was close to dying his family apparently sought to refuse to allow him to be buried there. ${ }^{23}$ Some authors believe that if, as seems to be the case, it was always intended that the Valle de los Caídos was to become the dictator's mausoleum, dedicating it to the fallen soldiers of the Civil War would have been a means to disguise the huge cost of constructing it. ${ }^{24}$

\section{The Treatment Given to the Valle de los Caídos in the HML: A Lost Opportunity}

With Franco dead, the Valle de los Caídos became a public monument managed by the Consejo de Administración del Patrimonio Nacional [Board of Directors of National Heritage]. It also became the place where those nostalgic for Francoism and supporters of the Falange went every November 20 ("20N") to pay tribute to the dictator and José Antonio Primo de Rivera (also buried there) on the anniversary of their deaths, something they continue to do, even after the commemoration lost

${ }^{21}$ Méndez, El Valle de los Caídos, 160; Sueiro, El Valle de los Caídos, 209. Furthermore, a document dated in 1976 on the reasons why the Valle de los Caídos Basilica was built, published by the FNFF, states that Franco "had planned to be buried with those who have given their life" to defend his cause. FNFF, Razones por las que se construyó la Basílica del Valle de los Caídos. Templo erigido por un gran español (Madrid: FNFF, 1976), 20. The FNFF was created in that same year with the objective of disseminating the remembrance and work of the dictator, and it was honorary presided over by his daughter until her death in 2017.

${ }^{22}$ Sueiro, El Valle de los Caídos, 208; Olmedo, El Valle de los Caídos, 338.

${ }^{23}$ Olmedo, El Valle de los Caídos, 339.

${ }^{24}$ Ibid., 338. 
its official nature. In the 1980s, groups opposing Francoism started organizing counterdemonstrations on "20N," some of them at the Valle de los Caídos, which ended in tense stand-offs.

The HML was passed in this context in $2007,{ }^{25}$ with the object of recognizing and extending rights to those persecuted during the Civil War and the dictatorship, promoting moral reparation, and recovering their personal and family memories. It also aimed at adopting complementary measures to eliminate divisive elements and unite Spanish society "en torno a los principios, valores y libertades constitucionales" (article 1.1) [around constitutional principles, values and liberties]. One of the aspects it sought to address was precisely the treatment that the symbols and monuments dedicated to the military uprising, the Civil War, and the repression of the dictatorship should be given. The HML did this by ordering their removal, except in the case of those of a strictly private nature or artistic, architectural or artistic-religious examples protected by law (article 15). The case of the Valle de los Caídos is specifically worth mentioning. Article 16 of the HML intended to eliminate the political connotations of this place by stating that it be regulated by the rules applying to places of worship and public cemeteries and expressly forbidding political events or acts related to the exaltation of the Civil War, of the actors involved, or of Francoism.

By focusing on avoiding disputes, the HML ended up giving an unsatisfactory, insufficient answer to the problem. By limiting itself to underscoring the religious nature of the Valle de los Caídos, the HML lost an opportunity to transform it into a centre for historical interpretation to remember the past in an objective and inclusive way, a demand made by different political groups

${ }^{25}$ Law 52/2007, of 26 December, por la que se reconocen y amplían derechos y se establecen medidas en favor de quienes padecieron persecución o violencia durante la guerra civil y la dictadura [recognizing and expanding the rights and establishing measures in favour of those who suffered persecution or violence during the Civil War and the dictatorship], published in Boletín Oficial del Estado, no. 310, 27 December 2007, 53410-6. 
in their alternative texts to the HML. ${ }^{26}$ Transforming the Valle de los Caídos into a place of remembrance was also in line with the suggestions made by the Parliamentary Assembly of the Council of Europe (PACE) in Recommendation 1736 (2006), on the need for international condemnation of the Franco regime. It urged the Spanish government to - among other things - "set up a permanent exhibition in the underground basilica at the Valle de los Caídos (Valley of the

${ }^{26}$ For example, article 14.3.1.1 of the Proposición de ley sobre Memoria Histórica Republicana y Antifascista, presented by Esquerra Republicana de Catalunya in November of 2005, proposed that it should be turned into a centre for information and dissemination of the memory of the repression in general and that of the prisoners who worked in its construction in particular, as well as of the entire repressive structure of work camps deployed by the dictatorship. Esquerra Republicana de Catalunya, "Proyecto de ley sobre Memoria Histórica Republicana y Antifacista," Equipo Nizkor, http://www.derechos.org/nizkor/espana/doc/esqley.html (accessed 15 September 2017). The Proposición de Ley de promoción de la recuperación y fomento de la Memoria y Cultura Democráticas, by the Parlamentary Group of Izquierda Verde-Izquierda Unida-Iniciativa per Catalunya Verds, proposed in that same month that the Valle de los Caídos, given its "strong symbolic content incompatible with our democratic culture," immediately be transformed into a Centro del Memorial de la Libertad [Liberty Memorial], where the proposed Instituto de la Memoria Democrática [Democratic Memory Institute] would be located (see articles 2 and 4); it also would feature a Museum of Repression, where Francoist items and remains collected all over the state would be exhibited (article 16.c). Izquierda Verde-Izquierda Unida-Iniciativa per Catalunya Verds, "Proyecto de ley de promoción de la recuperación y fomento de la Memoria y Cultura Democráticas,” Equipo Nizkor, http://www.derechos.org/nizkor/espana/doc/iuley.html (accessed 15 September 2017). 
Fallen) outside Madrid - where Franco is buried - explaining how it was built by the republican prisoners." 27

However, the HML did not take into account domestic demands nor the international recommendations when it came to deciding the monument's destiny. When the law was discussed in Congress, the socialist government defended it by stating that the Valle de los Caídos never again would be a "place for the exaltation of Francoism nor of any crusade." It added that the law established that the management foundation had, among other objectives, "to honour the memory of all those who died in the Civil War and to further knowledge of that period in history," 28 so only peace and democratic values would be exalted there. ${ }^{29}$

The latter statement seems rather illusory in practice given that the HML's solution to the issue of Franco's grave has not cancelled out its symbolic value from the point of view of ending impunity and of the reparation of the victims of Francoism. The dictator's corpse still can be honoured in a public place where, following Calleja, "democracy has not arrived." ${ }^{30}$ Furthermore,

${ }^{27}$ Council of Europe Parliamentary Assembly, Need for international condemnation of the Franco regime, Recommendation 1736, 17 March 2006, para. 8.2.3.

${ }^{28}$ Additional provision 6 of the HML.

${ }^{29}$ Remarks by Vice-president María Teresa Fernández de la Vega during the discussion of the draft law that recognizes and expands rights and establishes measures in favour of those who suffered persecution or violence during the Civil War and the dictatorship. Congreso de los Diputados, "Debates de totalidad de iniciativas legislativas - Proyecto de Ley por la que se reconocen y amplían derechos y se establecen medidas en favor de quienes padecieron persecución o violencia durante la Guerra Civil y la Dictadura," Diario de Sesiones del Congreso de los Diputados (Pleno y Diputación Permanente), no. 222, VII Term, 14 December 2006, 11270.

${ }^{30}$ Calleja, El Valle de los Caídos, 213. 
the foundation that manages the site - created in 1957, in Franco's time ${ }^{31}$ - hardly could achieve this objective since it is currently in a legal limbo, its functions and representation having been assigned to the Consejo de Administración del Patrimonio Nacional. ${ }^{32}$

It would have been more in keeping with the reparative objective of the law to adopt one of the proposals in some of the alternative bills that suggested the state reach an agreement with Franco's family to move his remains to a pantheon of their choice, the expenses to be covered by the state. ${ }^{33}$ The need to desacralize the Valle de los Caídos and remove Franco's grave so his family could honour his remains in a private location was also defended during the discussion of the HML. ${ }^{34}$ This view was also shared by the Comisión de Expertos para el Futuro del Valle de los Caídos [Commission of Experts on the Future of the Valle de los Caídos] (CEFVC), created by the government in 2011 to assess potential work that ought to be carried out on this monument, given it had been damaged by the passage of time. ${ }^{35}$ In its report, the Commission even suggested not intervening and leaving it to time to turn the complex into rubble, but then discarded that possibility

\footnotetext{
${ }^{31}$ See note 15 above.
}

${ }^{32}$ Final provision 3 of the Law 23/1982, of 16 June, reguladora del Patrimonio Nacional, published in Boletín Oficial del Estado, no. 148, 22 June 1982, 16949; Calleja, El Valle de los Caídos, 215. ${ }^{33}$ Izquierda Verde-Izquierda Unida-Iniciativa per Catalunya Verds, “Proyecto de ley,” article 16.c). ${ }^{34}$ See the remarks by Francisco Rodríguez Sánchez in the name of the Bloque Nacionalista Galego, and Aitor Esteban Bravo's, of the Partido Nacionalista Vasco, during the discussion of the draft law that recognizes and expands rights and establishes measures in favour of those who suffered persecution or violence during the Civil War and the dictatorship. Congreso de los Diputados, "Debates de totalidad," 11276, 11278, respectively.

35 Order PRE/1396/2011, of 27 May, published in Boletín Oficial del Estado, no. 127, 28 May 2011, 53148-53. 
out of respect for the memory of the victims. ${ }^{36}$ Instead, it proposed a total re-signification of the monument by turning it into a war victim memorial, which implied moving Franco's corpse to a place designated by his family or to a dignified and more suitable place, given that he had not died in the war. ${ }^{37}$

The discussion was reopened by the end of 2013 when the socialist parliamentary group presented a proposition to reconvert the Valle de los Caídos into a "space for the culture of reconciliation, collective democratic memory, dignifying and recognition of all the victims of the Spanish Civil War and the dictatorship." This included the exhumation of Franco's body and its transfer to another place. ${ }^{38}$ In 2015, Judge Baltasar Garzón and lawyers Manuel Ollé and Eduardo Ranz, in exercise of the right of petition, asked the government to remove Franco's remains from the Valle de los Caídos and to create a space of memory in that place. The cabinet rejected the petition in September 2016 and its decision was appealed to the Supreme Court, which in March 2017 dismissed the appeal on technical grounds. ${ }^{39}$ In November 2016, a non-binding motion brought before the national parliament by Esquerra Republicana insisted on the need to follow the recommendations of the CEFVC, again without success. ${ }^{40}$

\footnotetext{
${ }^{36}$ CEFVC, Informe, para. 5.

${ }^{37}$ Ibid., para. 31.

${ }^{38}$ Grupo Parlamentario Socialista, "Proposición no de Ley presentada por el Grupo Parlamentario Socialista, relativa a la ejecución de un Plan para resignificar la función del Valle de los Caídos,” Boletín Oficial del Congreso de los Diputados, no. 356, X Term, 11 November 2013, 6-8.

${ }^{39}$ Tribunal Supremo (Sala de lo Contencioso-Administrativo, Sección Cuarta), Sentencia no. 429/2017, of 13 March 2017.

${ }^{40}$ Grupo Parlamentario de Esquerra Republicana, "Proposición no de Ley presentada por el Grupo Parlamentario de Esquerra Republicana, sobre el cumplimiento de las recomendaciones del Grupo
} 
Surprisingly, the situation changed in May 2017, when yet another non-binding motion brought forward by the socialist group, on the effective application and development of the HML and calling for the removal of Franco's remains from the Valle de los Caídos,${ }^{41}$ was approved by the Congress of Deputies with only one vote against (from a deputy from the right-wing Popular Party). The rest of the Popular Party parliamentary group, which initially opposed the motion, finally opted to abstain. Nevertheless, its spokesperson in the debate made it clear they considered that a "party political use" of the history of Spain was being made. In any case, despite the result of the vote, it is unlikely that Franco will leave the Valle de los Caídos for the moment. The motion approved is not binding on the government, which predictably will take no action in this regard given its extreme reluctance to develop a policy against impunity and in favour of preserving the memory of the crimes of Francoism.

Almost forty years after his death, the dictator still creates controversy ${ }^{42}$ and challenges the construction of a collective memory that restores victims' dignity, which in turn reveals the

de Expertos para el Futuro del Valle de los Caídos," Boletín Oficial del Congreso de los Diputados, no. 60, XII Term, 29 November 2016, 6-7.

${ }^{41}$ Grupo Parlamentario Socialista, "Proposición no de Ley presentada por el Grupo Parlamentario Socialista, relativa a la efectiva aplicación y desarrollo de la Ley de Memoria Histórica," Boletín Oficial del Congreso de los Diputados, no. 112, XII Term, 28 February 2017, 8-11.

${ }^{42}$ Apart from the discussions on impunity and reparations to victims, a series of events in the last years illustrate the controversial continuing influence of Franco in Spanish society. An example of this is the removal from the ARCOMadrid 2012 modern art fair of Always Franco (a sculpture of Franco in dress uniform placed inside a Coca-Cola vending machine), with which the artist, Eugenio Merino, intended to reflect upon the way Spanish society has frozen the image of the dictator. "Eugenio Merino, creator of 'Always Franco': 'My idea was to show that Franco is frozen," Cadena SER, 14 February 2012, http://www.cadenaser.com/cultura/articulo/eugenio- 
negative impact that the treatment given to his body has had on the fight against impunity in Spain. Indeed, his gravesite is a symbol of the continued existence of Francoism in Spanish public life and is closely connected to the unpunished atrocities committed during Franco's regime, including impunity guaranteed by the 1977 Amnesty Law. Had the dictator's memory been given a private status undoubtedly would have made it easier to end his legacy during the transition and his human rights violations most likely would have been punished. In fact, it is no surprise that this demand started to gain momentum in an attempt to symbolically end impunity after the efforts to punish the crimes committed during Francoism proved unsuccessful.

merino-autor-always-franco-idea-era-mostrar-francorefrigerado/csrcsrpor/20120214csrcsrcul_11/Tes (accessed 15 September 2017). The FNFF (one of whose objectives is carrying out "a full range of activities aiming towards the glorification of Franco and the preservation of his legacy, including any that might contribute to the achieving of these ends") had filed a complaint against Merino stating his work was an offensive caricature of Franco (FNFF, complaint of 29 March 2012, factual basis 1) that damaged his honour (ibid., factual basis 3). The complaint eventually was dismissed as the work was deemed an exercise of creative freedom that did not constitute an offence against honour (Tribunal de Primera Instancia no. 26 de Madrid, Sentencia 150/13, 15 July 2013, legal basis 4). Other examples include the publication on social media in 2013 of a series of photographs of members of the youth wing of the Spanish Popular Party holding Francoist flags. At the same time, a city mayor of the same party proclaimed himself Francoist in an interview and showed a Franco portrait he keeps in his office, and another mayor paid tribute to "those fallen defending God and Spain" and authorized a market selling profascist and pro-Nazi products. Luz Sánchez-Mellado, "El peligroso juego del 'aguilucho," El País, 5 October 2013, http://politica.elpais.com/politica/2013/10/05/actualidad/1380992517_354386.html (accessed 15 September 2017). 


\section{Pinochet's Ashes: The Result of the Struggle Against Impunity}

Augusto Pinochet died at the Military Hospital in Santiago de Chile on 10 December 2006 at the age of ninety-one, only a year before the approval of the HML in Spain. He was interred in a chapel located on the family property of Los Boldos, a significant change in the initial plans of the dictator, who would have preferred to be buried in a monumental mausoleum. This decision seems to have been influenced to a large degree by Chilean society's new perspective as a result of criminal investigations beginning in the 1990s regarding crimes committed during the dictatorship, which rendered vulnerable a great symbolic public figure, as Wilde points out. ${ }^{43}$ Therefore, it can be stated that the treatment of Pinochet's corpse, compared with that of Franco's, was decisively conditioned by the firm initiatives launched outside and inside the country to fight against impunity for the serious human rights violations committed in Chile during his rule, initiatives that already had encouraged activities aimed at preserving the memory of those violations.

Now the old dictator's legal position at the time of his death will be examined, and then we will evaluate the impact this might have had on the treatment of Pinochet's corpse, as well as on the memory of the human rights violations committed during his dictatorship.

\section{From a Dictator's Aspirations of Monumental Eternity to the Criminal Investigation of}

\section{a Suspect}

Fernando Olmedo recounts that during a stopover on Gran Canaria island on the return flight after attending Franco's funeral, Pinochet commented to the then-acting civil governor of the island how impressed he had been by the Valle de los Caídos and how much he would like to build a similar

\footnotetext{
${ }^{43}$ Alexander Wilde, “Irruptions of Memory: Expressive Politics in Chile's Transition to Democracy," Journal of Latin American Studies 31, no. 2 (1999): 474.
} 
monument to house his own remains when his time came. ${ }^{44} \mathrm{He}$ also was attracted by the idea of building a tomb imitating Napoleon's crypt. ${ }^{45}$ His delirium of monumental grandeur for all eternity was thwarted by events between the end of his rule (the 1988 plebiscite and the coming to power of Patricio Aylwin in 1990, democratically elected in 1989) and his death.

After leaving the presidency, Pinochet remained as commander-in-chief of the army, a position he left in March of 1998 to immediately assume the position of senator-for-life on the basis of the 1980 Constitution drawn up during his rule and approved in a referendum, which was heavily criticized for irregularities associated with it. ${ }^{46}$ Pinochet continued on the public stage under the protection of the Amnesty Decree Law passed in $1978,{ }^{47}$ but many victims wanted to end his impunity. Given the existence of the amnesty law, alternatives were sought to obtain justice outside Chile. Thus, cases were filed in Italy, Argentina, Spain, France, and Belgium. In January 1998, criminal complaints against Pinochet for the atrocities perpetrated during the dictatorship began to reach the Chilean courts. The first one was filed by Gladys Marín Millie, General Secretary of the Communist Party, for the kidnapping and murder in 1976 of members of the party's clandestine leadership, including her husband, Jorge Muñoz. Judge Juan Guzmán Tapia ruled that forced

\footnotetext{
${ }^{44}$ Olmedo, El Valle de los Caídos, 348.

${ }^{45}$ As told by Pinochet to Hernán Guiloff, a businessman and union leader, during his detention in London. Ibid., 349.

${ }^{46}$ Lifetime senators were abolished by Constitutional Reform Law no. 20050, "Reforma constitucional que introduce diversas modificaciones a la constitución política de la República,” published in Diario Oficial, no. 38.246, of 26 August 2005, 5.

${ }^{47}$ Decree Law no. 2191, granting amnesty to the persons therein and for the crimes therein, published in Diario Oficial, no. 30.042, 19 April 1978, 1.
} 
disappearance was an on-going kidnapping, to which the amnesty law was not applicable, ${ }^{48}$ marking a turning point in the Chilean judiciary's action in the face of human rights violations committed under Pinochet's government. It also opened the doors to more criminal complaints (such as those relating to the 1973 Caravan of Death; Operation Colombo, organised in 1975; and the torture and disappearances committed at Villa Grimaldi, a clandestine DINA [National Intelligence Directorate, Pinochet's secret police] detention centre, among others). ${ }^{49}$

Even though he was aware of legal action against him in other countries, Pinochet decided to travel to London for medical treatment in September of 1998. His position as senator-for-life guaranteed him immunity in Chilean courts, but not abroad. Taking advantage of these circumstances, in October of that year the Spanish Audiencia Nacional [National High Court] issued an international warrant for his detention and he was arrested on the $16^{\text {th }}$ of that month in London. Following a series of court decisions, including a granting of extradition, ${ }^{50}$ the UK eventually refused Pinochet's extradition in 2000 for "humanitarian reasons" claiming that he was

\footnotetext{
${ }^{48}$ See his views on this in Juan Guzmán Tapia, En el borde del mundo. Memorias del juez que procesó a Pinochet (Barcelona: Anagrama, 2005), 139-40.
}

${ }^{49}$ Summary table of the complaints filed until April 2001 in Centro de Estudios Miguel Enríquez (CEME), Resumen de querellas presentadas y tramitadas en el proceso contra Augusto Pinochet Ugarte y otros, substanciado por el Ministro de Fuero Juan Guzmán Tapia, Causa 2182-98, Corte de Apelaciones de Santiago de Chile, Archivo Chile, http://www.archivochile.com/Dictadura_militar/pinochet/juicios/DMjuiciopino80001.pdf (accessed 15 September 2017).

${ }^{50}$ Bow Street Magistrates' Court (Mr Ronald David Bartle, Metropolitan Magistrate), The Kingdom of Spain v. Augusto Pinochet Ugarte, judgment of 8 October 1999, TNI, https://www.tni.org/es/node/8462 (accessed 15 September 2017). 
not fit to face trial. ${ }^{51} \mathrm{He}$ returned to Chile in March of that year, where his immunity was lifted in August in relation for the Caravan of Death case. Judge Guzmán prosecuted Pinochet in December that year and issued an arrest warrant in 2001. However, some months later, the Appeals Court temporarily set aside the case due to Pinochet's health. The case finally was dropped in July 2002 on the grounds of his suffering from moderate dementia.

In the following months and years, the former dictator was successively stripped of his immunity, prosecuted, and placed under house arrest for different cases related to crimes committed during his dictatorship, cases that continued to be filed until November 2005, when he was found mentally fit to be tried in the Operation Colombo case. Further to that, the discovery of secret accounts at the Riggs Bank in the USA - which would have enabled him to amass a vast fortune without legal justification - also caused his prosecution and arrest that same month, this time for tax evasion and forgery. When he died, he was under house arrest in connection with the Caravan of Death case. A few weeks before that, on November 25, his birthday, he had assumed "political responsibility for all he had done" in a written statement read by his wife. ${ }^{52}$ His death prevented him from being held accountable in court, but justice pursued him right until his very end.

\section{Private Remembrance of Pinochet Versus the Collective Memory of the Dictatorship}

Pinochet had dreamed of his own Valle de los Caídos or a tomb like Napoleon's. However, he settled for commissioning his cousin - during his first years in power - with the construction of a

\footnotetext{
${ }^{51}$ See the Pinochet case in Diego L. Garrido, Mercedes G. Arán and Concepción E. Hernández, eds., Crimen internacional y jurisdicción universal. El caso Pinochet (Valencia: Tirant lo Blanch, 2000).

52 "Pinochet dice que asume 'la responsabilidad política de todo lo obrado,"” El Clarín de Chile, 11 November 2005, http://www.elclarin.cl/index2.php?option=com_content\&do_pdf=1\&id=4839 (accessed 15 September 2017).
} 
family mausoleum at the General Cemetery of Santiago, ${ }^{53}$ where the democratically elected presidents are buried, ${ }^{54}$ including Salvador Allende. It is also the place holding the Memorial del Detenido Desaparecido y Ejecutado/a Politico/a, a memorial to the thousands of Chileans whose remains have not been found, or who were murdered for political reasons. The former dictator's parents and parents-in-law were laid to rest in the notably austere ${ }^{55}$ Pinochet-Hiriart mausoleum. ${ }^{56}$ However, before dying, Pinochet told his family he did not want to be buried, but rather cremated, so as to prevent his grave from being desecrated by his detractors, and he wanted the urn with his ashes to remain with the family. ${ }^{57}$

Many in Chile received word of Pinochet's death on 10 December 2006 - Human Rights Day - with great joy, and public demonstrations to express that joy came swiftly. However, it also made the split in Chilean society clear, as other sectors expressed their sorrow for the dictator's death and showed their support. Ultimately, Pinochet's aspirations of eternal political glory did not materialize: the Chilean government announced there would be no official mourning period nor a funeral with state honours; public events related to his memory focused on his army credentials.

${ }^{53}$ Fernando Villagrán and Marcelo Mendoza, La muerte de Pinochet: crónica de un delirio (Santiago: Planeta, 2003), 13-15; Olmedo, El Valle de los Caídos, 349.

${ }^{54}$ Except for Gabriel González Videla, president between 1946 and 1952, buried in La Serena. 55 "Disappointing," "disgraceful," “mediocre," in the words of Villagrán and Mendoza. Villagrán and Mendoza, La muerte de Pinochet, 17-18.

${ }^{56}$ Pinochet wanted the mausoleum to bear both his surnames, but his wife was opposed to this. Olmedo, El Valle de los Caídos, 349-50; Villagrán and Mendoza, La Muerte de Pinochet, 13-14. 57 "Víctimas y abogados lamentan que Pinochet haya muerto sin ser condenado," Terra, 12 December 2006, Archivo Chile, http://www.archivochile.com/Dictadura_militar/muertepin8/muertepin8_0239.pdf, 5-6 (accessed 15 September 2017). 
The government authorized flags to fly at half-mast on army premises and at military units. His body lay in state for a whole day at the Military School in Santiago, where the army paid tribute to him in his capacity as former commander-in-chief. A large number of his supporters - around sixty thousand people - filed past his coffin. ${ }^{58}$ The funeral included a mass at the Military School, followed by funeral ceremonies at the Honour Courtyard of this institution. ${ }^{59}$ Only the minister of defence attended in representation of the government.

The possibility of his ashes being buried at the General Cemetery of Santiago, or in another public institution, such as the Military School, was ruled out. His family decided to take them to Los Boldos, a family-owned estate in the Valparaíso region, approximately $130 \mathrm{~km}$ southeast of Santiago, where Pinochet had died under house arrest for the Caravan of Death case. His remains were placed in a private chapel that the former dictator had ordered built in 1998 to celebrate his $55^{\text {th }}$ wedding anniversary and are guarded by soldiers. The only setbacks have been the embargo placed on the land by the courts in 2010 in the context of the Riggs case, and the subsequent discovery of 182 marihuana plants on the property, the latter being semi-abandoned, according to the family and the media. ${ }^{60}$

58 “Tributes Paid at Pinochet Funeral," BBC News, 12 December 2006, http://news.bbc.co.uk/2/hi/americas/6171387.stm (accessed 15 September 2017).

${ }^{59}$ Ejército de Chile, Comunicado Oficial sobre el Fallecimiento del CGL. Augusto Pinochet Ugarte, 10 December 2006, Archive, http://archive-cl.com/cl/e/ejercitodechile.cl/2013-0502_1996613_64/Ej\%C3\%A9rcito_de_Chile_Noticias/ (accessed 15 September 2017).

${ }^{60}$ See Sebastián Labrín, "Revelan investigación en la que el OS-7 encontró plantación de marihuana en parcela Los Boldos," La Tercera, 6 July 2011, 9; María Elizabeth Pérez, "El panorama actual del predio de familia Pinochet," La Tercera, 6 July 2011, 9. 
The private nature of Pinochet's grave has not totally solved divisions in Chilean society. On certain dates, such as 11 September, there is still unrest and disturbances, ${ }^{61}$ and the former dictator still has supporters. However, he and his legacy are increasingly condemned. ${ }^{62}$ Furthermore, there has been no need for the state to decide how to treat the dictator's remains from the memorial point of view. This has allowed it to focus on the public remembrance of the human rights violations committed during the dictatorship, in line with what had happened during the first years of democracy. Such trend later declined, only to be rekindled in 1998 when Pinochet was arrested in London. In fact, some authors see this year as the moment when historical memory erupted in Chile, in Wilde's words. ${ }^{63}$ The vitriolic reaction that this caused among Pinochet's supporters

${ }^{61}$ See, for example, "Presidente tras 11 de septiembre: 'Llegó el momento que los chilenos nos unamos en contra de la violencia y de la delincuencia,"” Patagonia RadioTV, 13 September 2013, https://www.patagoniaradio.cl/2013/09/13/presidente-tras-11-de-septiembre-llego-el-momento-quelos-chilenos-nos-unamos-en-contra-de-la-violencia-y-de-la-delincuencia/ (accessed 15 September 2017).

${ }^{62}$ According to a survey carried out on the $40^{\text {th }}$ anniversary of the military coup, the number of Chileans who justified it had decreased, and three-quarters of the population believed the divisions caused by the military regime persisted. More than 50\% stated that Pinochet's government had been bad or very bad, and $76 \%$ described him as a dictator (versus $66 \%$ in 2006 ); $9 \%$ claimed he had been one of the best heads of state of the $20^{\text {th }}$ century, half the number recorded in 2006. Barómetro CERC, A cuarenta años del golpe militar, September 2013, https://es.slideshare.net/nacioncl/a-4dcadas-del (accessed 15 September 2017).

${ }^{63}$ Alexander Wilde, "Irruptions of Memory,” 489; Peter Winn, “El pasado está presente. Historia y memoria en el Chile contemporáneo," in Historizar el pasado vivo en América Latina, ed. Anne Pérotin-Dumon (Santiago: Universidad Alberto Hurtado - Centro de Ética, 2007), 20, http://www.historizarelpasadovivo.cl/index.html (accessed 15 September 2017); Katherine Hite, 
contrasts with the half-hearted reactions to his arrest in 2005 for the crimes committed during Operation Condor, following the release of the Valech report a year earlier. ${ }^{64}$ As Winn recalls, there were lukewarm words of concern for the former dictator's health from the army and right-wing civilians, and the army even admitted responsibility for the tortures inflicted by its members. ${ }^{65}$ This reveals that the narrative portraying Pinochet as Chile's saviour had declined in favour of the recognition of the bloody years the country had gone through during his dictatorship. Yet, on 20 December 2006, a few days after Pinochet's death, a group of congressional representatives presented a draft law setting up monuments to his memory in Santiago, Iquique and Valparaíso. ${ }^{66}$

"La superación de los silencios oficiales en el Chile posautoritario," in Historizar el pasado, 31; Pablo Azócar, Epitafio para un tirano (Madrid: Editorial Popular, 1999), 189.

${ }^{64}$ Comisión Nacional sobre Prisión Política y Tortura, Informe, Santiago, 2004, Biblioteca del Congreso Nacional de Chile, http://www.bcn.cl/bibliodigital/dhisto/lfs/Informe.pdf (accessed 15 September 2017). The Valech Commision II (officially “Comisión Asesora Presidencial para la Calificación de Detenidos Desaparecidos, Ejecutados Políticos y Víctimas de Prisión Política y Tortura") drew up a second report in 2011. Comisión Asesora Presidencial para la Calificación de Detenidos Desaparecidos, Ejecutados Políticos y Víctimas de Prisión Política y Tortura, Informe Santiago, 2011, Centro de Documentación - Museo de la Memoria y los Derechos Humanos, http://www.cedocmuseodelamemoria.cl/wp-content/uploads/2012/08/Informe2011.pdf (accessed 15 September 2017).

${ }^{65}$ Winn, “El pasado está presente," 21.

${ }^{66}$ Cámara de Diputados de Chile, "Proyecto de ley que autoriza la construcción de un monumento en las ciudades de Santiago, Iquique y Valparaíso, en memoria del ex Presidente de la República y ex Comandante en Jefe del Ejército, Capitán General don Augusto Pinochet Ugarte,” BoletínCámara de Diputados de Chile, no. 4744-24, http://www.camara.cl/pley/pley_detalle.aspx?prmID=5131\&prmBL=4744-24 (accessed 15 
The proposal was not retained. By contrast, other initiatives, such as the one leading to the opening of the Museum of Memory and Human Rights in 2010, have become a reality.

\section{Final Remarks}

Franco and Pinochet have much in common, such as having died, unpunished, of natural causes. However, what happened after they died differentiates them, as reflected in the respective treatment their corpses received as a result both of historical circumstances and of the impact of initiatives to end their impunity. These two variables caused a separation in terms of the control these dictators achieved over their desired final resting place, a huge monumental complex in the case of Franco, while Pinochet had to make do with his ashes being placed in a chapel in his family estate.

From a historical point of view, there is no denying that the length of their rule necessarily affected the extension of their power beyond death. Thus, while Franco remained in power right until he died, Pinochet was forced to abandon power after he lost the 1988 national referendum.

September 2017). The text of the bill stated that it was "a moral duty to commemorate him and his work," adding that "the virtues of the democratic system under which we live today, as well as our economic development ... are a legacy of policies implemented during the military government and it is only just that they be recognized and acknowledged." In relation to this and other initiatives to praise the memory of Pinochet, Katherine Roberts Hite and Eliana Loveluck have said that "[m]emorials are commemorations: how does one memorialize a man who for so many brought terror, death, and the destruction of democracy? We say there should be no memorial to Pinochet at all, ever." Katherine R. Hite and Eliana Loveluck, "How to Remember Pinochet," CommonDreams, 3 January 2007, http://www.commondreams.org/views06/0103-50.htm (accessed 31 October 2013; site now discontinued; alternative site: https://groups.yahoo.com/neo/groups/armchairactivist/conversations/messages/15547 (accessed 15 September 2017). 
Furthermore, we cannot ignore either the great advances in the protection of human rights at the international level - including the establishment of principles governing the fight against impunity from a human rights perspective within the framework of the UN Commission on Human Rights between the death of Franco in 1975 and that of Pinochet in 2006.

The evolution of international human rights law clearly affected, in different ways, the social perception of each of these dictators inside and outside Spain and Chile, and the victims' demands after each of them died - they were much firmer in the case of Pinochet compared to that of Franco. When the former died, a number of court cases were underway against him for serious violations of human rights, which led to a perception that the formerly all-powerful dictator was no longer untouchable in Chilean society.

From the point of view of the fight against impunity, an unpunished dictator dying of natural causes takes on a strong symbolic nature for both his supporters and his detractors. It is therefore essential to tone down this symbolism by consigning posthumous memory to the private sphere, so it does not interfere with the democratic momentum in the public sphere. Setting up public memorials to honour a dead dictator reveals a clear lack of consistency: the violation of human rights is in every way a disgraceful practice unworthy of exaltation. In this regard, from the perspective of the protection and promotion of human rights, what happened in Chile with the dead body of Pinochet is much more appropriate than the half-hearted solution provided by the Spanish HML.

The public nature of Franco's gravesite - even when there has been an intention to depoliticize the place - means that its future is still linked to the state institutions and implies an acceptance of keeping it in the public sphere as the heritage of every Spaniard, funded by the state. The increasing demands to exhume Franco's body confirm that his corpse remains an obstacle to the full recognition of his victims and the restoration of their dignity. The only way to prevent his body from enjoying impunity forever is to act, so the dictator is no longer part of democratic life. 
Translated from French by Eamonn G. McDonagh and Virginia Hormaeche. 